\title{
密集市街地における住宅の耐震化促進のための 簡易耐震補強方法とセットバックに関する評価
}

\author{
水野 智雄 1 宮島 昌克 ${ }^{2}$ \\ 1学生会員 金沢大学大学院自然科学研究科博士後期課程 (9 920-1192 石川県金沢市角間町) \\ E-mail: n.mizuno.3kd.2@gmail.com \\ 2正会員 金沢大学大学院自然科学研究科教授 (下 920-1192 石川県金沢市角間町) \\ E-mail: miyajima@t.kanazawa-u.ac.jp
}

\begin{abstract}
2006年に耐震改修促進法が改正され，行政において，住宅の耐震診断・耐震改修の促進が図られている しかし，密集市街地では，耐震補強の方法や費用の面，建築基準法の接道規定により建替えや改築が困難 な場合がある．弚こで，本研究では，建築事業者を対象としたアンケート調査により，確保すべき耐震性 能の程度に関する認識及び耐震化が促進される可能性のある低廉で簡易な耐震補強方法に関する賛否を確 認するとともに，住民を対象としたアンケート調査により，セットバックに関する方策を提案し，賛否を 確認した . 弚の結果，建築事業者は行政よりも安全側の考えであることが判明した . また，住民の耐震化 意向には，接道の狭あい状況やセットバックの程度はほとんど影響しないことが判明した .
\end{abstract}

Key Words : questionnaire surveys, construction companies, simple method of seismic retrofit, width of roads, citizens' consciousness, renovation, earthquake-resistant structures

\section{1.はじめに}

\section{(1) 研究の背景}

1995 年 1 月 17 日に発生した阪神・淡路大震災では， 地震による直接的な死者が 5,502 人，この約 $90 \% 力$ 建築 物の倒壤や家具の転倒によるものであつた ${ }^{11}$. くは 1981 年に改正された建築基準法による耐震基準以 前に建築された住宅・建築物による被害であつた ${ }^{2)}$.

1995年に「耐震改修促進法」か制定された後も，2004 年 10 月の新潟県中越地震など大きな被害か溌生した地 震か瀕発しているが , 建築物の耐震化が進まない状況か ら，国土交通省の住宅・建築物の地震防災推進会議にお いて，2005 年 6 月に「住宅および特定建築物について 現状 $75 \%$ の耐震化率を 10 年後に $90 \%$ とする」と提言さ れた ${ }^{3)}$.

2006 年には耐震改修促進法か改正され, 地方自治体 における耐震改修促進計画の策定による計画的な耐震化 の推進，建築物の所有者等に対する指導等の強化，支援 制度の充実といったことか盛り込まれるとともに，国土 交通省において耐震化率を2015 年までに 90\%とするた めの基本方針が示された ${ }^{4)}$.

以上を踏まえて，地方自治体では，市町村内の住宅・ 建築物について耐震診断・耐震改修を計画的・総合的に 促進するため, 耐震改修促進計画力順次策定され，耐震
診断，耐震改修に関する補助制度も実施されている ${ }^{5)}$. 住宅耐震化の状況を表-1 に示す . 2005 年の国土交通 省の会議て提言された耐震化率 $75 \%$ 数字は, 表-1に 示す 2003 年の国土交通省の推計值か根拠となっている. この推計值が示された当時の耐震化のペースとしては， 2015 年までに耐震化率 90\%というのは難しいものの, 2010 年時点で $80 \%$ を超えるペースであったと推察され $3^{6)}$.

表-1 住宅戶数 ${ }^{6)}$

\begin{tabular}{|l|l|l|}
\hline & \multicolumn{1}{|c|}{ 住宅総戶数 } & \multicolumn{1}{c|}{ j5戶建木造 } \\
\hline 全数 & 約 4,700万戶 & 約 2450万戶 \\
\hline 话耐震性か不十分 & 約1,150万戶 & 約 1,000万 \\
& 約 25\%) & 約 40\%) \\
\hline
\end{tabular}

※国土交通省 2003年推計值 . 共同住宅含む．

※耐震性力不十分な住宅は，1998 年の約 1,400 万戶に比べ 250

万戶減.うち耐震改修によるもの約32万戶と推計.

表-2 住宅·土地統計調査 ${ }^{7}$ ～9)

\begin{tabular}{|c|c|c|c|}
\hline \multirow[b]{2}{*}{ 調査年 } & \multirow[b]{2}{*}{ 住宅総数 } & \multicolumn{2}{|c|}{ 1980年以前の建築 } \\
\hline & & F数 & $\begin{array}{c}\text { 前回調查との比 } \\
\text { 較 }\end{array}$ \\
\hline 1998年 & 約 4,390万戶 & 約 2,120 万戶 & - \\
\hline 2003年 & 約 4,600万戶 & 約 1,760 万戶 & 約 360 万戶減 \\
\hline 2008年 & 約 4,960万户 & 約 1,500万戶 & 約 170 万戶減 \\
\hline
\end{tabular}


しかし，表- 2 に示す総務省が実施した「住宅・土地 統計調査」 ${ }^{7) ~ 9)}$ によれば，2003 年から 2008 年の 5 年 間は, 2003 年以前の 5 年間よりも，1980 年以前に建築 された住宅の減少か鈍化していることがうかがえる．

このまま推移すれば, 新築物件数の増加により, 見か け上，耐震化率は上昇するが，1981 年の新耐震基準を 満たさない住宅が, 長期にわたり, 多数 , 残ってしまう 恐れがあると考えられる .

例えば，金沢市へのヒアリングによると，木造住宅の 耐震診断・設計・改修工事の件数は, 補助制度を拡充し た 2008 年度以降において 120 件程度であるが , これに 対し，2005 年度，2006 年度に実施された金沢市地震被 害想定調査において, 内陸活断層である森本・富樫断層 帯地震力発生した場合, 木造建物の被害については, 大 破 14, 801 棟，中破 10,821棟，計 25, 622棟と想定されて おり，行政施策だけでは，まち全体の建物の耐震化によ る防災性向上か困難であることがうかがえる．

特に，密集市街地においては，地震による既存不適格 の木造住宅の倒壤により，火災力発生し延焼する恐れが あり，狭あい道路の閉塞によって，住民の避難や消火・ 救助活動ができない恐れがあるなど，密集市街地におけ る木造住宅の耐震化促進は喫緊の課題と言える .

このような観点をふまええ，国においては，都市計画法 に基づく市街地整備事業，あるいは, 防災街区整備促進 法に基づく防災街区整備地区計画を都市計画として定め ることにより，密集市街地の面的・一体的な開発整備が 推進されているが, 厳しい財政事情のなか, 地方自治体 にとっては，莫大な費用負担が必要となる．

以上のような状況では, 行政において現行の補助金制 度による耐震化促進など防災性向上のための施策を継続 しても, 光の効果が不明瞭であることから，行政の厳し い財政事情を勘案し，施策を再評価する必要がある。

一方，密集市街地の住民の立場に着目すれば，密集市 街地特有の問題として, 住宅の接道か狭あいであり，法 令の制約により建替えができない場合があること，長屋 型式の住宅が多く単独での建替え・改修か困難であるほ か , 住民の所得の問題があり，費用のかかる耐震改修が 困難であることなどが, 耐震化が促進されない要因であ ることが考えられる．

\section{(2) 既往の研究}

住宅の耐震化促進に関する既往の研究の時期としては， 阪神・淡路大震災の後から 2006 年の耐震改修促進法が 改正され，自治体において，本格的に耐震改修促進計画 か策定されたり，補助制度が創設されるまでが大多数を 占める .

ソフト面では，一般市民を対象としたアンケート調査
により，意識を把握し，耐震化が進まない要因，地震対 策行動の誘因を分析するもの, 自治体の補助制度導入等 を提案するものなどがある.

目黑ら ${ }^{10) ， 11}$ は, 既往の研究を分析するとともに，ア ンケート調査を実施し，住宅の安全性や継承に関する意 識，耐震診断や耐震補強の実施・判断理由について回答 を得て，これらの結果を家族構成・経済的状況・住宅の 状態などの観点から分析している. 光の結果として, 近 所の人の影響, 補強コスト低減に関する情報提供力洏震 補強への誘因として強く働くこと，また，高額な補強費 用，工事依頼先への信頼不足，建築技術の情報提供不足 の3つに大別される阻害要因が卓越していることを挙げ るとともに,多世帯で耐震診断・補強を誘発する制度 の導入, 耐震診断から改修計画立案・業者選定 ·工法· コスト妥当性・改修後の保守などの総合支援の実施を提 案している。

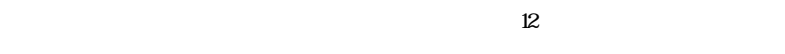
売買・賃貸時の説明責任制度, 耐震改修補助制度, 生命 保険・損害保険耐震性割引制度, 中古住宅耐震性価格査 定制度, 減災耐震改修促進制度, 地震倒壊色険建築物利 用制限制度の6つを抽出し，促進されない原因の仮説と して, 地震で自分の建築物か椡壊し死亡するなどと考え ていないこと, コスト面では, 耐震診断費用が高いこと などと設定し，インターネットアンケート調査による原 因考察や公的助成など新たな制度的対策の考案等を行な っているほか, 地震保険と自治体補助制度等をリンクさ せ，単純明快な体系に改善することを提唱するもの ${ }^{13)}$ がある。

以上のほか, 耐震診断 (簡易耐震診断 , 一般診断) に 要する日数を比較・検証し, 促進されない原因を究明す

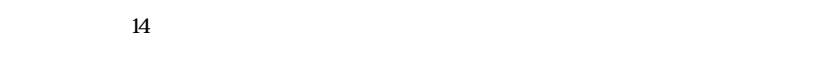
住民，民間業者，行政及び専門家か協働して，耐震化普 及啓発活動を行う取組み事例 ${ }^{15}$ がある.

ハード面の研究については, 改修方法に関する実験な どの技術的検討，簡易て低廉な補強方法・工法の提案や 事例などがある ${ }^{16) ~ 18) ． ~}$

しかし , 住宅の耐震化については, 密集市街地の住宅 の改修に有効と考えられる簡易な工法について, 商品の 宣伝活動を主眼とした一部建築事業者による視点ではな く, 建築事業者における一般的な視点での評価・研究が 行われていない .

また，密集市街地における研究として，山本ら ${ }^{19}$ ，20 が, 東京都墨田区京島地区を対象に, 路地 (狭あい道 路）の幅員などの実態把握をするとともに，道路幅員や セットバックに関する住民意識を調査した事例があるほ か, 佐藤ら ${ }^{21)}$ が, 大分県別府市及び大分市を対象に， 路地空間の状況を把握し, 老朽化の解消, 防災面の向上 
を図ることができる方策の一つとして , 建築基準法第 42 条第 2 項及び第 3 項の適用による路地空間の保存 · 維持の可能性を探った事例がある．

しかし，狭あい道路が , 住民の耐震化意向への影響に 関する研究か行われておらず，また，セットバックにつ いて，具体的な道路幅員と住民意識との関連を探った研 究か行われていない.

\section{2. 研究の位置づけと目的}

既往の研究では, 幅広く，樣々な角度からの検討・検 証か行われ，耐震化の誘因や阻害要因も明らかにされ， アンケート調査結果により個人属性ごとの意識も分析さ れているが, 提案される制度等は, 厳しい財政事情の行 政の施策に反映するものとして示される傾向にある .

しかし，1(1)で述べたとおり，行政施策だけでは， まちの防災性向上に大きな進展がみられないと考えられ る.また，1(2)で述べたとおり，建築事業者が住宅の 耐震化に関し，一般的にどのような認識をもっているの か, また，密集市街地の住民の視点から，狭あい道路が 耐震化意向に影響しているのかか明らかになっていない， 乥こで, 本研究では, 密集市街地において, 大地震時 における減災のための最も基本となる，建替え，改修に よる住宅の耐震化によって防災性向上を図ることに着目 し, 弚れにつなげるための基礎的研究と位置づけて，建 築事業者を対象としたアンケート調査及び密集市街地の 居住者である一般市民を対象としたアンケート調査を行 い, 次の事項を明らかにすることを目的とし，密集市街 地における耐震化の促進につながる方策の方向性を見い 出すこととする．

(1) 建築事業者における住宅の耐震化に関する認識及 び簡易な耐震補強方法に関する賛否を把握する．

(2) 住民の住宅の耐震化意向を探りつつ，住宅前面の 接道状況の影響について把握する.

(3) 住宅前面の接道状況を考慮した建替え方策を提案 し，住民による評価を得る．

\section{3. 建築事業者を対象としたアンケート調査}

\section{(1) 調査の概要}

本研究では, 工務店など住宅等の設計・施工を業務と している石川県内の建築事業者を対象にアンケート調査 を実施した . なお，建築事業者の選定にあたっては，後 述の「住民を対象としたアンケート調査」を金沢市内で 実施することにあわせ , 金沢市内での業務に携わる可能
性があることを考慮した .

1(2)で述べたとおり，既往の研究 ${ }^{10)}$ ，11において， 「補強コスト低減に関する情報提供力洏震補強への誘因 として強く働くこと, 高額な補強費用, 工事依頼先への 信頼不足，建築技術の情報提供不足の3つに大別される 阻害要因が卓越していること」と抽出されている .

これらをふまえ，この調査においては，技術面につい ては, コスト低減の可能性の視点から，耐震補強の程度 に対する意見を求めるとともに，建築主の金銭的な負担 感，工事に対する抵抗感を軽減するため採用されつつあ る，補強の程度を軽微にする方法や低価格で簡易な補強 方法に対する賛否を尋ねた。

（2）調査票の配付・回収状況

調査表の配付, 回収状況は, 次のとおりである.

(1)期間

2010年 11月 29日～12月 13日

(2)配付 $\cdot$ 回収方法

郵送による。

(3)配付 $\cdot$ 回収数

配布数: 100 票

回收数 : 24 票

回収率 : $24 \%$

(4)調査内容の要旨

- 資本金, 従業員数, 建築士等の有資格者数

・確保すべき上部構造評点に対する考え方

・補強の程度を軽微にする方法に対する賛否

・低価格で簡易な補強方法に対する賛否

\section{(3) 建築事業者の概要}

アンケートに協力してくれた建築事業者の事業規模を 示す資本金，従業員数，有資格者の延へ人数は, 表-3 のとおりである .なお，表-3 を掲げたのは，調査対象 が, 全国展開をしている大手企業ではなく，住民に身近 な工務店など中小企業であり，かつ，有資格者による判 断のもとアンケートの回答があったことを示すためであ る。

(4) 調査結果

a) 確保すべき耐震性能に関する意見

建築事業者の「確保すべき上部構造評点」 ${ }^{22)}$ に対す る考え方を表 4 に示す。

「倒褱しない」耐震性能の「15以上」が 35\%，「一 応倒壊しない」耐震性能の「10以上 15 未満」が $65 \%$ であった. 
表-3 建築事業者の概要

\begin{tabular}{|c|c|c|c|c|c|c|}
\hline & 資本金 & 徙業員数 & & 格者数 & 正へ人数) & \\
\hline & (万円) & (人) & $\begin{array}{c}\text { 一級建 } \\
\text { 築士 }\end{array}$ & $\begin{array}{c}\text { 二級建 } \\
\text { 築士 }\end{array}$ & $\begin{array}{c}\text { 木造建 } \\
\text { 築士 }\end{array}$ & 弚の他 \\
\hline A & 3800 & 8 & 4 & 2 & 0 & 0 \\
\hline B & 2000 & 19 & 3 & 2 & 0 & 0 \\
\hline$C$ & 8500 & 21 & 2 & 1 & 0 & 1 \\
\hline D & 3000 & 17 & 2 & 2 & 0 & 0 \\
\hline E & 2500 & 10 & 5 & 1 & 0 & 0 \\
\hline $\mathrm{F}$ & 2000 & 17 & 2 & 4 & 0 & 0 \\
\hline G & 4500 & 23 & 9 & 5 & 0 & 0 \\
\hline $\mathrm{H}$ & - & - & 1 & 2 & 0 & 0 \\
\hline 1 & 2000 & 27 & 1 & 5 & 0 & 0 \\
\hline $\mathrm{J}$ & 2400 & 20 & 3 & 8 & 1 & 0 \\
\hline K & 2000 & 23 & 6 & 1 & 0 & 0 \\
\hline $\mathrm{L}$ & 3200 & 10 & 3 & 3 & 0 & 0 \\
\hline $\mathrm{M}$ & 3330 & 6 & 1 & 4 & 0 & 0 \\
\hline $\mathrm{N}$ & 2000 & 40 & 1 & 2 & 0 & 0 \\
\hline 0 & 4800 & 17 & 1 & 7 & 0 & 9 \\
\hline $\mathrm{P}$ & 4600 & 21 & 1 & 1 & 0 & 5 \\
\hline $\mathrm{Q}$ & 3000 & 38 & 9 & 7 & 0 & 0 \\
\hline $\mathrm{R}$ & 21900 & 78 & 13 & 15 & 0 & 0 \\
\hline$S$ & 2000 & 39 & 0 & 2 & 0 & 7 \\
\hline$T$ & 4000 & 13 & 2 & 9 & 0 & 10 \\
\hline U & 2000 & 51 & 2 & 0 & 0 & 0 \\
\hline V & 2500 & 30 & 1 & 3 & 0 & 0 \\
\hline W & 2000 & 6 & 0 & 4 & 0 & 0 \\
\hline$x$ & 3500 & 28 & 6 & 7 & 0 & 21 \\
\hline
\end{tabular}

注)「炎の他」は, 一級・二級の建築施工管理技士 , 土木施 工管理技士である

表-4「確保すべき上部構造評点」に対する考え方

\begin{tabular}{|c|c|c|}
\hline 賛否 & 回答数 & 割合 \\
\hline 15以上 & 7 & $35.0 \%$ \\
\hline 10以上15未満 & 13 & $65.0 \%$ \\
\hline 弚の他 & 0 & $0 \%$ \\
\hline 計 & 20 & $100 \%$ \\
\hline
\end{tabular}

[参考]木造住宅の耐震診断では, 一般診断法に用いられる上 部構造評点力洏震性能の目安として用いられることが多い.
15以上は「倒壊しない」
10以上15末満は「一応倒壊しない」
0.7 以上 10 末満は「倒壊する可能性がある」
0.7末満は「倒壊する可能性が高い」

b) 簡易な耐震改修・補強方法に関する評価 ${ }^{16)}$ １8

一般住民における耐震補強に対する金銭的な抵抗感や

工事への抵抗感を軽減することか期待できるとともに，

工事等の制約条件が厳しい場合に有効であると提唱され ている木造住宅に関する「補強の程度を軽微にする方 法」を大きく4パターンに整理し，建築事業者に尋ねた．
(1) 1階のみ補強する方法

「1階のみ補強する方法」に対する賛否について表- 5 に示す．「賛成」，「条件次第て賛成」をあわせ，80\% を超えた，「条件次第で賛成」の条件として，「屋根の 重みで2階も破壊するお光れがあり，建物形状による」 などか挙げられた，一方，反対の理由として，「建物全 体で性能を考えるべき」などか学げられた .

ここで, 回答数が少ないため，あくまで参考であるが， 建築事業者において, 上部構造評点と耐震改修・補強方 法の考え方について , 何らかの傾向がみられるのではな いかと仮説を立て，「確保すべき上部構造評点」に対す る考え方と「1階のみ補強する方法」に対する賛否の関 係についてクロス集計を行った（表-6）．有意水準 0.05 (P-5\%直 5.991) としてカイ 2 乗検定を行った結 果 , 有意な差はみられなかった .

表-5「1階のみ補強する方法」に対する賛否

\begin{tabular}{|c|c|c|}
\hline 賛否 & 回答数 & 割合 \\
\hline 賛成 & 13 & $61.9 \%$ \\
\hline 条件次第て賛成 & 5 & $23.8 \%$ \\
\hline 反対 & 3 & $14.3 \%$ \\
\hline 計 & 24 & $100 \%$ \\
\hline
\end{tabular}

表- $6 「$ 確保すべき上部構造評点」に対する考え方と 「1階のみ補強する方法」に対する賛否の関係

\begin{tabular}{|c|c|c|c|c|}
\hline \multirow{2}{*}{$\begin{array}{c}\text { 確保すべ } \\
\text { き上部構 } \\
\text { 造評点 }\end{array}$} & \multicolumn{3}{|c|}{ ０1階のみを補強する方法賛否 } & \multirow[b]{2}{*}{ 合計 } \\
\hline & 賛成 & $\begin{array}{l}\text { 条件次第 } \\
\text { て賛成 }\end{array}$ & 反対 & \\
\hline \multirow{3}{*}{ 15以上 } & 4 & 1 & 1 & 6 \\
\hline & $66.7 \%$ & 16. $7 \%$ & 16. $7 \%$ & $100 \%$ \\
\hline & $30.8 \%$ & $33.3 \%$ & $33.3 \%$ & $56.2 \%$ \\
\hline \multirow{3}{*}{$\begin{array}{l}10 \sim 15 \\
\text { 末満 }\end{array}$} & 9 & 2 & 2 & 13 \\
\hline & $69.2 \%$ & $15.4 \%$ & $15.4 \%$ & $100 \%$ \\
\hline & $69.2 \%$ & $66.7 \%$ & $66.7 \%$ & $43.8 \%$ \\
\hline \multirow{3}{*}{ 合計 } & 13 & 3 & 3 & 19 \\
\hline & $68.4 \%$ & $15.8 \%$ & $15.8 \%$ & $100 \%$ \\
\hline & $100 \%$ & $100 \%$ & $100 \%$ & $100 \%$ \\
\hline
\end{tabular}
上段 : 回答数, 中段 : 行ごとの割合, 下段 : 列ごとの割合 カイ 2乗値 0.012

\section{（2）1室のみ補強する方法}

「1室のみ補強する方法」に対する賛否について, 表 - 7 に示す。「賛成」，「条件次第で賛成」をあわせ， 50\%を超えたが，「反対」も 40\%を超えた．反対の理 由としては, 構造のバランスか悪くなること, 必ずしも その部屋に居ないと考えられることなどか学げられた .

ここで, 前述の1と同樣の観点で，「確保すべき上部 構造評点」に対する考え方と「1室のみ補強する方法」 に対する賛否の関係についてクロス集計を行った（表8) . 有意水準 0.05 ( $\mathrm{P}=5 \%$ 徝 5.991) としてカイ 2 乗検 定を行った結果, 有意な差はみられなかった . 
表- 7 「1室のみ補強する方法」に対する賛否

\begin{tabular}{|c|c|c|}
\hline 賛否 & 回答数 & 割合 \\
\hline 賛成 & 10 & $47.6 \%$ \\
\hline 条件次第て賛成 & 2 & $9.5 \%$ \\
\hline 反対 & 9 & $429 \%$ \\
\hline 計 & 久 & $100 \%$ \\
\hline
\end{tabular}

表- 8 「確保すべき上部構造評点」に対する考え方と 「1室のみ補強する方法」に対する賛否の関係

\begin{tabular}{|c|c|c|c|c|}
\hline \multirow{2}{*}{$\begin{array}{c}\text { 確保すべ } \\
\text { き上部構 } \\
\text { 造評点 }\end{array}$} & \multicolumn{3}{|c|}{ 口1室のみを補強する方策口賛否 } & \multirow[b]{2}{*}{ 合計 } \\
\hline & 賛成 & $\begin{array}{l}\text { 条件次第 } \\
\text { て賛成 }\end{array}$ & 反対 & \\
\hline \multirow{3}{*}{ 15以上 } & 2 & 0 & 4 & 6 \\
\hline & $33.3 \%$ & $\%$ & $66.7 \%$ & $100 \%$ \\
\hline & $22 \%$ & \% & 44. $4 \%$ & $316 \%$ \\
\hline \multirow{3}{*}{$\begin{array}{l}10 \sim 15 \\
\text { 未満 }\end{array}$} & 7 & 1 & 5 & 13 \\
\hline & $53.8 \%$ & 7. $7 \%$ & $38.5 \%$ & $100 \%$ \\
\hline & $77.8 \%$ & $100 \%$ & $55.6 \%$ & $68.4 \%$ \\
\hline \multirow{3}{*}{ 合計 } & 9 & 1 & 9 & 19 \\
\hline & $47.4 \%$ & $5.3 \%$ & $47.4 \%$ & $100 \%$ \\
\hline & $100 \%$ & $100 \%$ & $100 \%$ & $100 \%$ \\
\hline
\end{tabular}

上段 : 回答数, 中段 : 行ごとの割合, 下段 : 列ごとの割合 カイ 2 乗值 1516

（3）外装の上から金属ブレースなど接合金属で補強する 方法

「外装の上から金属ブレースなど接合金属で補強する 方法」に対する賛否について，表-9に示す．「賛成」，

「条件次第で賛成」をあわせ $60 \%$ であった。「条件次 第で賛成」の条件として，外観力悪くなるのて建築主の 理解が必要などか学げられた．また，「反対」は $40 \%$ にものぼった . 反対の理由として , 外観の問題 , 外壁の 耐用年数が短く問題が生じる可能性があることなどが挙 げられた 。

ここで，前述の(1)，(2)と同樣の観点で，「確保すべき 上部構造評点」に対する考え方と「外装の上から金属ブ レースなど接合金属で補強する方法」に対する賛否の関 係についてクロス集計を行った（表-10）．有意水準 0.05 (P-5\%值 5.991) としてカイ2 乗検定を行った結 果, 有意な差はみられなかった .

表-9「外装の上から金属吅吼ど接合金属て補強する方 法」に対する賛否

\begin{tabular}{|c|c|c|}
\hline 賛否 & 回答数 & 割合 \\
\hline 賛成 & 8 & $40.0 \%$ \\
\hline 条件次第て賛成 & 4 & $20.0 \%$ \\
\hline 反対 & 8 & $40.0 \%$ \\
\hline 計 & 20 & $100 \%$ \\
\hline
\end{tabular}

表-10「確保すべき上部構造評点」に対する考え方と 「外装の上から金属ブレースなど接合金属で補強す る方法」に対する賛否の関係

\begin{tabular}{|c|c|c|c|c|}
\hline \multirow{2}{*}{$\begin{array}{l}\text { 確保すべ } \\
\text { き上部構 } \\
\text { 造評点 }\end{array}$} & \multicolumn{3}{|c|}{ 口外装の上から接合金属補強賛否 } & \multirow[b]{2}{*}{ 合計 } \\
\hline & 賛成 & $\begin{array}{l}\text { 条件次第 } \\
\text { て賛成 }\end{array}$ & 反対 & \\
\hline \multirow{3}{*}{ 15以上 } & 2 & 1 & 2 & 5 \\
\hline & $40 . \%$ & $20 . \%$ & $40 . \%$ & $100 \%$ \\
\hline & $28 \%$ & $33.3 \%$ & $25 . \%$ & $27.8 \%$ \\
\hline \multirow{3}{*}{$\begin{array}{l}10 \sim 15 \\
\text { 未満 }\end{array}$} & 5 & 2 & 6 & 13 \\
\hline & $38.5 \%$ & $15.4 \%$ & 46. $2 \%$ & $100 \%$ \\
\hline & $714 \%$ & $66.7 \%$ & $75 \%$ & $72 \%$ \\
\hline \multirow{3}{*}{ 合計 } & 7 & 3 & 8 & 18 \\
\hline & $38.9 \%$ & 16. $7 \%$ & 44. $4 \%$ & $100 \%$ \\
\hline & $100 \%$ & $100 \%$ & $100 \%$ & $100 \%$ \\
\hline
\end{tabular}

上段 : 回答数, 中段 : 行ごとの割合, 下段 : 列ごとの割合 カイ2 乗値 0.079

(4) ポリエステル系ベルト等で補強する方法

柱・梁・筋かいなど接合部を「ポリエステル系ベルト 等で補強する方法」への賛否について，表11 に示す．

「賛成」，「条件次第で賛成」をあわせ $60 \%$ を超えた . 「条件次第て賛成」の条件として，接着などの「性能保 証」などか学げられた . また，「反対」は 40\%近くに のぼった . 反対の理由として , 接着などの信用性 , 安全 性に課題があることなどか学げられた .

ここで, 前述の(1)から(3)と同樣の観点で, 「確保すべ き上部構造評点」に対する考え方と「ポリエステル系べ ルト等で補強する方法」に対する賛否の関係についてク ロス集計を行った（表-12），有意水準 0.05 (P-5\%值 5.991) としてカイ 2 乗検定を行った結果，有意な差は みられなかった。

表-11「ポリエステル系ベル卜等で補強する方法」に対する賛否

\begin{tabular}{|c|c|c|}
\hline 賛否 & 回答数 & 割合 \\
\hline 賛成 & 9 & $429 \%$ \\
\hline 条件次第て賛成 & 4 & $19.0 \%$ \\
\hline 反対 & 8 & $381 \%$ \\
\hline
\end{tabular}

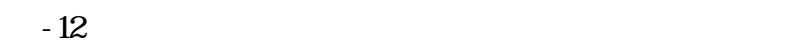

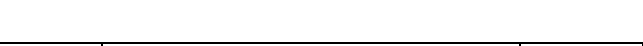

\begin{tabular}{|c|c|c|c|c|}
\hline \multirow{2}{*}{$\begin{array}{c}\text { 確保すべ } \\
\text { き上部構 } \\
\text { 造評点 }\end{array}$} & \multicolumn{3}{|c|}{ ロポリエステル系ベルト等で補強口賛否 } & \multirow[b]{2}{*}{ 合計 } \\
\hline & 賛成 & $\begin{array}{l}\text { 条件次第 } \\
\text { て賛成 }\end{array}$ & 反対 & \\
\hline \multirow{3}{*}{ 15以上 } & 4 & 1 & 1 & 6 \\
\hline & $66.7 \%$ & 16. $7 \%$ & 16. $7 \%$ & $100 \%$ \\
\hline & $30.8 \%$ & $33.3 \%$ & $33.3 \%$ & $56.2 \%$ \\
\hline \multirow{3}{*}{$\begin{array}{l}10 \sim 15 \\
\text { 未満 }\end{array}$} & 9 & 2 & 2 & 13 \\
\hline & $69.2 \%$ & 15. $4 \%$ & $15.4 \%$ & $100 \%$ \\
\hline & $69.2 \%$ & $66.7 \%$ & $66.7 \%$ & $43.8 \%$ \\
\hline \multirow{3}{*}{ 合計 } & 13 & 3 & 3 & 19 \\
\hline & $684 \%$ & $15.8 \%$ & $15.8 \%$ & $100 \%$ \\
\hline & $100 \%$ & $100 \%$ & $100 \%$ & $100 \%$ \\
\hline
\end{tabular}

上段 : 回答数, 中段 : 行ごとの割合, 下段 : 列ごとの割合 カイ 2 乗値 2544 
(5)まとめ

以上を総括すると，次のとおりである．

(1)全社が「一応倒壊しない」耐震性能である上部構造

評点10以上を確保すべきだと考えている．

(2)簡易な耐震改修・補強方法については，建物全体と

しての性能評価が必要であることや外観に問題が あることか指摘されている。

以上より，建築事業者においては，自治体において耐 震化を促進させるため補助金の適用を認めている，コス 卜低減につながるような上部構造評点の10末満への低 減や簡易な耐震改修・補強方法の適用などよりも，建物 全体を評価した上での安全性の確保を図るべきであると 考えられていることがうかがえる.なお，上部構造評点 と簡易な耐震改修・補強方法とは大きな関連性はみられ なかった。

\section{4. 住民を対象としたアンケート調査}

\section{(1) 調査の概要}

本研究では, 一般住民の住宅の耐震化に関する意識を 把握し分析するため，住宅の耐震性向上等に関するアン ケート調査を実施した .なお, 密集市街地を対象とした 既往の研究については, 国において地震発生の確率が高 く，甚大な被害力想定されている首都圏などを対象とし

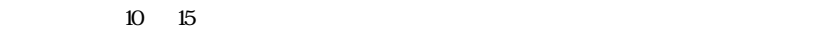
ら,本研究における対象地区としては, 戦禍を免れ, 老 朽木造住宅力数多く残っており，まちなみ保全に取り組 んでいる金沢市を選定した .さらに，金沢市が「特別消 防対策区域」に指定している密集市街地の中から，人口 密度や道路の狭小の程度を参考に, 図-1に示す増泉 1 丁目, 幸町, 菊川2丁目, 石引2丁目, 横山町・暁町, 森山1丁目の6地区を選定した .ここで「特別消防対策 区域」とは，「木造住宅か密集し道路か狭く，㴥方車の 通行が困難な区域」とされ，火災延焼だけでなく，大地 震時において, 住宅の倒壊と道路閉塞により，避難行動 か困難になることか懸念される区域のことである .

(2) 調査票の配付・回収状況

調査表の配付 , 回収状況は, 次のとおりである .

(1)期間： 配付期間 2010年 12月 4日〜12日 回収期間 2010年 12月 11日〜21日

(2)配付・回収方法：各世帯への訪問による .

(3)配付・回收数：配付数：640票 回收数 : 450 票

回收率 : $70.3 \%$

注) 回収数 450 票のうち, アンケート調査表の質
問項目に対して十分な回答を記入している有 効回答数は 439 票であつた .

(4)調査内容の要旨

調査内容としては, 既往の研究をうまえた項目を盛 り込むとともに , 住民に対しては , 耐震性向上のみを 目的とした改修だけでなく，日常生活の利便性の向上 を目的とした改修の際に，耐震性も向上させることを 推奨したほうか高い効果か得られるのではないかと仮 定し, 密集市街地特有の物理的な影響が考えられる自 家用車の保有や駐車場の確保の状況等に関する項目も 盛り込んだ.

項目の骨子は , 次のとおりである .

・現在の建物（延床面積, 構造等) の状況認識

・現在の建物の所有権 , 建築年

・いつから住んでいる

・居住意向 (住み続けたいかどうか)

·建物の耐震性向上の意向

耐震性向上の意向・向上の程度

自家用車の保有，駐車場の確保の状況

・建替えにあたっての接道と住宅のセットバッ クに関する方策に関する賛否

·家族の属性

家族構成, 家族各々の性別・年齢・職業, 世 帯年収

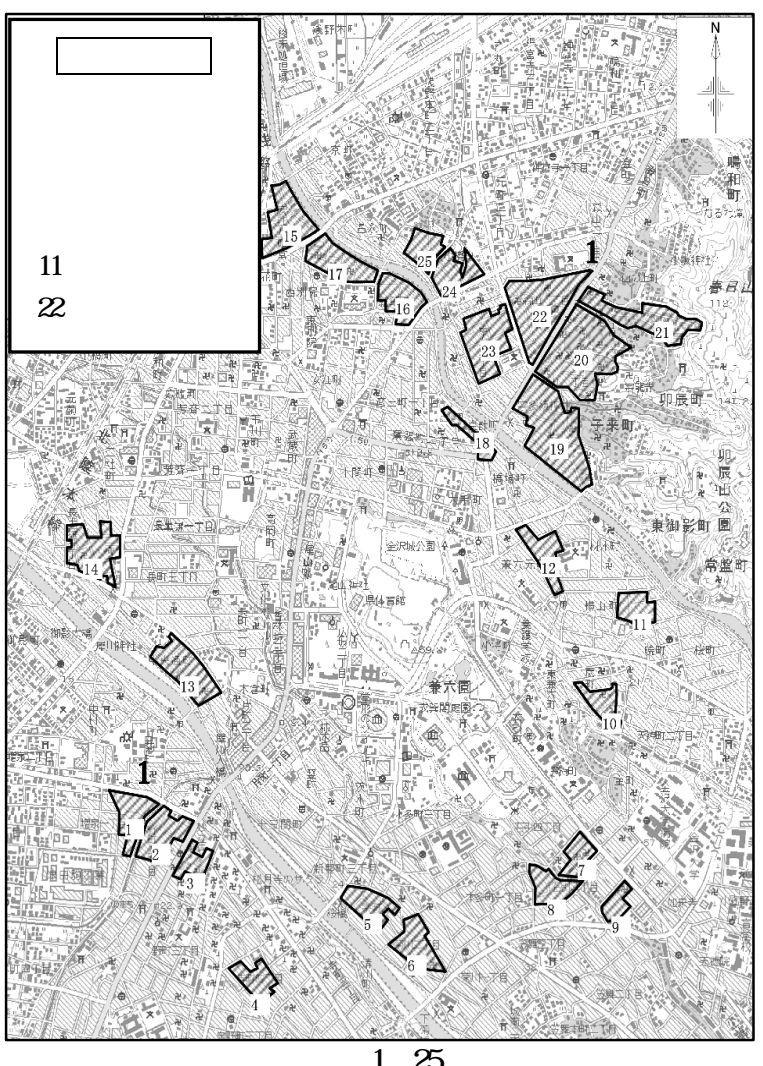

注) 1〜25は「特別消防対策区域」

图-1 調查対象地区 
(5)調査対象地区の人口等

金沢市が公表している，調査時期の直近における 2010 年 12 月 1 日現在の住民基本台帳による調査対象 地区の世帯数 , 人口及び 65 歳以上の人口比率を表- 13 に示す . 65 歳以上の人口比率は, 金沢市総数が 21\% であるのに対し，調査対象地区では，すべての町丁で 30\%を超えている．

表-13 調査対象地区の世帯数・人口

\begin{tabular}{|c|c|c|c|c|c|}
\hline \multirow{2}{*}{$\begin{array}{l}\text { 統計区 } \\
\text { 町丁名 }\end{array}$} & \multirow{2}{*}{ 世帯数 } & \multirow{2}{*}{ 人口 } & \multicolumn{2}{|c|}{ 性別 } & \multirow{2}{*}{$\begin{array}{l}\text { 65歳以 } \\
\text { 上比率 }\end{array}$} \\
\hline & & & 男 & 女 & \\
\hline 金沢市総数 & 188,346 & 445,969 & 214,951 & 231,008 & $21 \%$ \\
\hline 増泉 1丁目 & 581 & 1,073 & 478 & 596 & $33 \%$ \\
\hline 幸町 & 591 & 1,163 & 536 & ๔27 & $33 \%$ \\
\hline 菊川 2丁目 & 490 & 1,037 & 473 & 564 & $32 \%$ \\
\hline 石引 2丁目 & 517 & 1,022 & 476 & 546 & $31 \%$ \\
\hline 横山町 & 526 & 1,138 & 517 & 61 & $33 \%$ \\
\hline 曉町 & 423 & 952 & 440 & 512 & $36 \%$ \\
\hline 森山1丁目 & 405 & 870 & 400 & 470 & $38 \%$ \\
\hline
\end{tabular}

\section{(3) 調査結果}

\section{a) 調査対象者の基本属性等}

アンケート調査における基本属性等の回答結果を表14から表 26 に示す .

特に世帯の属性に注目すると, 家族の人数が 2 人以下 の世帯が $60 \%$ を超え，主な働き手の年齢が 60 歳代 , 70 歳以上の世帯があわせて 40\%を超え, また, 世帯の年 収が500万円未満の世帯が65\%を超えている .

表-14 建物の延べ床面積

\begin{tabular}{|l|r|r|}
\hline \multicolumn{1}{|c|}{ 延へ床面積 } & \multicolumn{1}{|c|}{ 回答数 } & \multicolumn{1}{c|}{ 割合 } \\
\hline $50 \mathrm{~m}^{2}$ 末満 & 14 & $5.2 \%$ \\
\hline $50 \mathrm{~m}^{2} \sim 100 \mathrm{~m}^{2}$ 末満 & 64 & $23 \% \%$ \\
\hline $100 \mathrm{~m}^{2} \sim 150 \mathrm{~m}^{2}$ 末満 & 90 & $33.2 \%$ \\
\hline $150 \mathrm{~m}^{2} \sim 200 \mathrm{~m}^{2}$ 末満 & 64 & $23 \% \%$ \\
\hline $200 \mathrm{~m}^{2}$ 以上 & 39 & $14.4 \%$ \\
\hline 合計 & 271 & $100 \%$ \\
\hline
\end{tabular}

表- 15 建物の構造

\begin{tabular}{|c|c|c|}
\hline 構造 & 回答数 & 割合 \\
\hline 木造 & 385 & $90.0 \%$ \\
\hline 鉄骨·軽量鉄骨 & 35 & $8 \%$ \\
\hline 鉄筋コンクリート & 5 & $12 \%$ \\
\hline その他 (木造と鉄骨の混合) & 2 & $0.5 \%$ \\
\hline 不明 & 1 & $0.2 \%$ \\
\hline 合計 & 428 & $100 \%$ \\
\hline
\end{tabular}

表-16 建物の所有権

\begin{tabular}{|c|c|c|}
\hline 構造 & 回答数 & 割合 \\
\hline 持家 & 403 & $92 \%$ \\
\hline 借家 & 34 & $7.8 \%$ \\
\hline 合計 & 437 & $100 \%$ \\
\hline
\end{tabular}

表-17 建築年

\begin{tabular}{|c|c|c|}
\hline 建築年 & 回答数 & 割合 \\
\hline ～1950年 & 92 & $225 \%$ \\
\hline 1961年～1959年 & 26 & $6.4 \%$ \\
\hline 1960年～1971年 & 54 & $13 \%$ \\
\hline 1972年～1981年 & 79 & 19. $3 \%$ \\
\hline 1982年～1992年 & $\pi$ & $18 \%$ \\
\hline 1993年～2000年 & 56 & 13. $7 \%$ \\
\hline 2001年〜 & 25 & $6.1 \%$ \\
\hline 合部 & 409 & 100 \\
\hline
\end{tabular}

表-18 入居年 (いつから住んているか)

\begin{tabular}{|c|c|c|}
\hline 入居年 & 回答数 & 割合 \\
\hline ～1950年 & 87 & $221 \%$ \\
\hline 1951年 1959年 & 34 & $8.7 \%$ \\
\hline 1960年 1971年 & ๔3 & $16 \%$ \\
\hline 1972年～1981年 & 59 & 15. \% \\
\hline 1982年～1992年 & ๔3 & $16 . \%$ \\
\hline 1993年～2000年 & 43 & $10.9 \%$ \\
\hline 2001年〜 & 44 & $11 \%$ \\
\hline 合計 & 393 & $100 \%$ \\
\hline
\end{tabular}

表-19 居住意向（住み続けたいかどうか）

\begin{tabular}{|c|r|r|}
\hline \multicolumn{1}{|c|}{ 居住意向 } & \multicolumn{1}{c|}{ 回答数 } & \multicolumn{1}{c|}{ 割合 } \\
\hline 住み続けたたい & 230 & $54.2 \%$ \\
\hline 住み続けざるを得ない & 160 & $37.7 \%$ \\
\hline 住み続けたたくない & 34 & $8 . \%$ \\
\hline 合計 & 424 & $100 \%$ \\
\hline
\end{tabular}

表-20 自家用車の保有

\begin{tabular}{|c|r|r|}
\hline 自家用車の保有 & 回答数 & \multicolumn{1}{|c|}{ 割合 } \\
\hline 持っている & 313 & $76.2 \%$ \\
\hline 持っていない & 98 & $238 \%$ \\
\hline 合計 & 411 & $100 \%$ \\
\hline
\end{tabular}

表-21 駐車場の確保の状況（駐車場の意向）

\begin{tabular}{|c|c|c|}
\hline 駐車場の確保の状况 & 回答数 & 割合 \\
\hline 十分足りている & 192 & $716 \%$ \\
\hline 敷地外の駐車場を借りたい & 9 & $3.4 \%$ \\
\hline 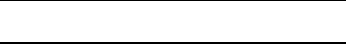 & 28 & 10. $4 \%$ \\
\hline 敷地前部に駐車場を設けたたい & 28 & 10. $4 \%$ \\
\hline クルマを使わないので不要 & 11 & 4. $1 \%$ \\
\hline 合計 & 208 & $10 \% \%$ \\
\hline
\end{tabular}

表-22 家族の人数

\begin{tabular}{|c|r|r|}
\hline 家族の人数 & \multicolumn{1}{|c|}{ 回答数 } & \multicolumn{1}{c|}{ 割合 } \\
\hline 1人 & 93 & $23.4 \%$ \\
\hline $2 人$ & 161 & $40.5 \%$ \\
\hline 3 人 & 65 & $16.3 \%$ \\
\hline 4 人 & 40 & $10.1 \%$ \\
\hline $5 人$ & 23 & $5.8 \%$ \\
\hline 6 人 & 16 & $4.0 \%$ \\
\hline 合計 & 398 & $100 \%$ \\
\hline
\end{tabular}


表-23 主な働き手の性別

\begin{tabular}{|c|c|c|}
\hline 主な働き手の性別 & 回答数 & 割合 \\
\hline 男性 & 161 & $79.3 \%$ \\
\hline 女性 & 42 & $20.7 \%$ \\
\hline 合計 & 203 & $10 \% \%$ \\
\hline
\end{tabular}

表-24 主な働き手の年齢

\begin{tabular}{|c|r|r|}
\hline 家族の人数 & \multicolumn{1}{|c|}{ 回答数 } & \multicolumn{1}{|c|}{ 割合 } \\
\hline 20 歳代 & 3 & $1.5 \%$ \\
\hline 30 歳代 & 22 & $11.1 \%$ \\
\hline 40 歳代 & 40 & $20.2 \%$ \\
\hline 50 歳代 & 48 & $24.2 \%$ \\
\hline 60 歳代 & 59 & $29.8 \%$ \\
\hline 70 歳以上 & 26 & $13.1 \%$ \\
\hline 合計 & 198 & $100 \%$ \\
\hline
\end{tabular}

表-25 主な働き手の職業

\begin{tabular}{|c|c|c|}
\hline 家族の人数 & 回答数 & 割合 \\
\hline 会社員 & 100 & $51 \%$ \\
\hline 自棠業 & 44 & $224 \%$ \\
\hline 公務員 & 11 & 5. $\%$ \\
\hline 団体職員 & 10 & $5.1 \%$ \\
\hline 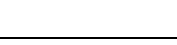 & 19 & 9. $7 \%$ \\
\hline 日雇い & 1 & $0.5 \%$ \\
\hline 無職 & 11 & 5. $6 \%$ \\
\hline 合計 & 196 & $100 \%$ \\
\hline
\end{tabular}

表-26 世帯の年収

\begin{tabular}{|c|c|c|}
\hline 家族の人数 & 回答数 & 割合 \\
\hline 200万円未満 & 39 & $16.3 \%$ \\
\hline 200万円～300万円未満 & 54 & $225 \%$ \\
\hline 300万円 400万円未末澫 & 36 & $15 . \%$ \\
\hline 400万円円 500万円円未満 & 28 & $117 \%$ \\
\hline 500万円〜 700万円未満 & 43 & $17.9 \%$ \\
\hline 700万円～1000万円未満 & 22 & $9.2 \%$ \\
\hline 1000万円～1500万円未満 & 16 & $6.7 \%$ \\
\hline 1500 万円以上 & 2 & $0.8 \%$ \\
\hline 合計 & 240 & $100 \%$ \\
\hline
\end{tabular}

b) 住宅の耐震性向上の意向

本研究では, 以下, 回答者の 90\%を占める木造住宅 の所有者に着目し，回答データを抽出して，耐震化の意 向及び保全を中心とした分析を行った .

住宅の耐震性向上の意向に関する回答結果を表- 27 に 示す．「向上させたい」が $56 \% ， 「$ 向上させなくてよ い」が44\%であった .

表-27 住宅の耐震性向上の意向

\begin{tabular}{|c|c|c|}
\hline 意向 & 回答数 & 割合 \\
\hline 向上せせい & 186 & $56 \%$ \\
\hline 向上させなくてよい & 146 & $44 . \%$ \\
\hline 合計 & 332 & $100 \%$ \\
\hline
\end{tabular}

ここで, 基本属性等により，耐震化意向が異なるかど うかを明らかにするため, 耐震性を「向上させたい」か 「向上させなくてよい」かを目的変数として, 数量化 $I$ 類分析を行った . 説明変数は, 個人属性を示す項目の他 に, アンケート調査の問いから，目的変数に影響を及ぼ すと予想される項目をいくつか取り上げ，クラメール連 関係数 ${ }^{23}$ を算出し (表-28) , クラメール連関係数が大 きいものから 10 個の項目を説明変数として採用し, 表29に示すケース1〜9の数量化川類分析を行った .

数量化川類の分析精度は, 相関比と判別的中点によっ て調へらられる . 実績值とサンプルスコアとの相関比の值 が大きいほど分析精度は高く, 基準の 0.5 を上回れは関 係式は予測に使えると判断する. また , 判別的中点の值 が大きいほど分析精度は高く, 基準の $75 \%$ 上回れば 関係式は予測に使えると判断する．また，レンジと偏相 関係数によって, 各説明变数の目的変数に対する貢献度 がわかる.これらの值が大きい項目ほど, 目的変数への 影響度が高い重要な項目である ${ }^{20}$ 。

表-28 住宅の耐震性向上の意向とアンケート項目のクラメー 儿連関係数

\begin{tabular}{|c|c|c|}
\hline 項目 (問い) & 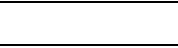 & 順位 \\
\hline 延へ床面積 & 0.123653 & 6 \\
\hline いつから住んでいるか & 0.027783 & 13 \\
\hline 居住意向 & 0.124220 & 5 \\
\hline 建築年 & 0.127891 & 4 \\
\hline 自家用車有無 & 0.168538 & 2 \\
\hline 駐車場の場所 & 0.034088 & 12 \\
\hline 駐車場の意向 & 0.101416 & 9 \\
\hline 家族の人数 & 0.119990 & 7 \\
\hline 主な働き手性別 & 0.097003 & 10 \\
\hline 主な働き手年齢 & 0.132377 & 3 \\
\hline 主な働き手職業 & 0.110052 & 8 \\
\hline 世帯の年収 & 0.247601 & 1 \\
\hline $\begin{array}{c}\text { 建物の形態 } \\
\text { (住居専用 , 店舗・作業所併用) }\end{array}$ & 0.020422 & 15 \\
\hline 建て方 (戶建て , 長屋) & 0.025583 & 14 \\
\hline 接道の幅員 & 0.049974 & 11 \\
\hline
\end{tabular}

表- 29 数量化川類分析のケース

\begin{tabular}{|c|c|c|c|c|c|c|c|c|c|c|}
\hline \multirow{2}{*}{ 項目 } & \multirow{2}{*}{$\begin{array}{l}\text { 順 } \\
\text { 位 }\end{array}$} & \multicolumn{9}{|c|}{ ケース } \\
\hline & & 1 & 2 & 3 & 4 & 5 & 6 & 7 & 8 & 9 \\
\hline 延べ床面積 & 6 & & & & & $\bigcirc$ & 0 & 0 & 0 & 0 \\
\hline 居住意向 & 5 & & & & 0 & 0 & 0 & 0 & 0 & 0 \\
\hline 建築年 & 4 & & & 0 & 0 & 0 & 0 & 0 & 0 & 0 \\
\hline 自家用車有無 & 2 & 0 & 0 & $\bigcirc$ & 0 & $\bigcirc$ & $\bigcirc$ & $\bigcirc$ & 0 & \\
\hline 駐車場の意向 & 9 & & & & & & & & 0 & \\
\hline 家族の人数 & 7 & & & & & & 0 & 0 & 0 & 0 \\
\hline 主な働き手性別 & 10 & & & & & & & & & 0 \\
\hline 主な働き手年齢 & 3 & & 0 & 0 & 0 & 0 & 0 & 0 & 0 & 0 \\
\hline 主な働き手職業 & 8 & & & & & & & $\mathrm{O}$ & 0 & 0 \\
\hline 世帯の年収 & 1 & 0 & 0 & 0 & 0 & 0 & $\bigcirc$ & 0 & 0 & 0 \\
\hline
\end{tabular}


ケース1〜9の数量化川類分析を行ったところ，ケー ス9で最も良い精度が得られた。ケース 9 の分析結果を 以下に示す．なお，ケース9では，「自家用車有無」，

「駐車場の意向」の回答数が1以下となるカテゴリーが 発生したため, 項目から削除した .

相関比は 0.6546 と基準の 0.5 を上回っており，また， 判別的中率は 91 1\%と基準の75\%を上回っているので， 関係式は予測に使えると判断した . 相関比, 判別的中率 両方か基準を上回り，この分析の精度は高いといえる。 説明変数を表-30に，また，数量化川類分析の結果を 表-31に示す。

表-30 説明変数

\begin{tabular}{|c|c|c|}
\hline 項目 & & カテゴリー \\
\hline \multirow[t]{7}{*}{ 世帯の年収 } & 1 & 20 0万円末満 \\
\hline & 2 & 200 万円〜 300 万円未満 \\
\hline & 3 & 300 万円〜 4 0 0万円未満 \\
\hline & 4 & 400 万円〜 500 万円未満 \\
\hline & 5 & 500 万円〜 70 0万円未満 \\
\hline & 6 & 700 万円〜 1000 万円未澫 \\
\hline & 7 & 1500 万円以上 \\
\hline \multirow[t]{5}{*}{ 主な働き手の年齢 } & 1 & 20,30 代 \\
\hline & 2 & 40 代 \\
\hline & 3 & 50 代 \\
\hline & 4 & 60 代 \\
\hline & 5 & 70 代 \\
\hline \multirow[t]{7}{*}{ 建築年 } & 1 & ～1950年 \\
\hline & 2 & 1951年〜1959年 \\
\hline & 3 & 1960年～1971年 \\
\hline & 4 & 1972年～1981年 \\
\hline & 5 & 1982年１992年 \\
\hline & 6 & 1993 年 2000 年 \\
\hline & 7 & 200 1年以降 \\
\hline \multirow[t]{3}{*}{ 居住意向 } & 1 & 住み続けたい \\
\hline & 2 & 住み続けざるを得ない \\
\hline & 3 & 住み続けたくない \\
\hline \multirow[t]{4}{*}{ 延べ床面積 } & 1 & $100 \mathrm{~m}^{2}$ 未満 \\
\hline & 2 & $100 \mathrm{~m}^{2} \sim 150 \mathrm{~m}^{2}$ 末満 \\
\hline & 3 & $150 \mathrm{~m}^{2} \sim 200 \mathrm{~m}^{2}$ 未満 \\
\hline & 4 & $200 \mathrm{~m}^{2}$ 以上 \\
\hline \multirow[t]{6}{*}{ 家族の人数 } & 1 & 1人 \\
\hline & 2 & 2人 \\
\hline & 3 & 3人 \\
\hline & 4 & 4人 \\
\hline & 5 & 5 人 \\
\hline & 6 & 6 人以上 \\
\hline \multirow[t]{5}{*}{ 主な働き手の職業 } & 1 & 会社員 \\
\hline & 2 & 自営業 \\
\hline & 3 & 公務員 \\
\hline & 4 & 団体職員 \\
\hline & 5 & パート・アルバイト \\
\hline \multirow[t]{2}{*}{ 主な働き手の性別 } & 1 & 男性 \\
\hline & 2 & 女性 \\
\hline
\end{tabular}

表-31 数量化 11 類分析の結果

\begin{tabular}{|c|c|c|c|c|c|}
\hline 項目 & カテゴリー & 個数 & $\begin{array}{l}\text { カテゴリー } \\
\text { スコア }\end{array}$ & レンジ & 偏相関係数 \\
\hline \multirow[t]{7}{*}{ 世帯の年収 } & 1 & 3 & 2079 & \multirow[t]{7}{*}{3.056} & \multirow[t]{7}{*}{0.662} \\
\hline & 2 & 9 & 0.425 & & \\
\hline & 3 & 8 & -0.196 & & \\
\hline & 4 & 4 & 0.484 & & \\
\hline & 5 & 13 & 0.206 & & \\
\hline & 6 & 9 & -0.977 & & \\
\hline & 7 & 10 & -0.433 & & \\
\hline \multirow{5}{*}{$\begin{array}{l}\text { 主な働き手 } \\
\text { の年齢 }\end{array}$} & 1 & 4 & 0.105 & \multirow[t]{5}{*}{1034} & \multirow[t]{5}{*}{0.45} \\
\hline & 2 & 14 & 0.243 & & \\
\hline & 3 & 11 & 0.615 & & \\
\hline & 4 & 23 & -0.419 & & \\
\hline & 5 & 4 & -0.235 & & \\
\hline \multirow[t]{7}{*}{ 建築年 } & 1 & 9 & 0.387 & \multirow[t]{7}{*}{1396} & \multirow[t]{7}{*}{0.454} \\
\hline & 2 & 6 & -0.328 & & \\
\hline & 3 & 5 & -0.889 & & \\
\hline & 4 & 6 & 0.507 & & \\
\hline & 5 & 12 & 0.258 & & \\
\hline & 6 & 12 & -0.196 & & \\
\hline & 7 & 6 & -0.143 & & \\
\hline \multirow[t]{3}{*}{ 居住意向 } & 1 & 39 & -0.13 & \multirow[t]{3}{*}{1008} & \multirow[t]{3}{*}{0.331} \\
\hline & 2 & 15 & 0.416 & & \\
\hline & 3 & 2 & -0.592 & & \\
\hline \multirow[t]{4}{*}{ 延べ床面積 } & 1 & 7 & 0.143 & \multirow[t]{4}{*}{0.534} & \multirow[t]{4}{*}{0.267} \\
\hline & 2 & 20 & -0.13 & & \\
\hline & 3 & 15 & -0.203 & & \\
\hline & 4 & 14 & 0.331 & & \\
\hline \multirow[t]{6}{*}{ 家族の人数 } & 1 & 6 & 0.483 & \multirow[t]{6}{*}{0.961} & \multirow[t]{6}{*}{0.498} \\
\hline & 2 & 19 & -0.474 & & \\
\hline & 3 & 8 & 0.487 & & \\
\hline & 4 & 9 & -0.332 & & \\
\hline & 5 & 9 & 0.344 & & \\
\hline & 6 & 5 & 0.421 & & \\
\hline \multirow{5}{*}{$\begin{array}{c}\text { 主な働き手の } \\
\text { 職業 }\end{array}$} & 1 & 28 & -0.408 & \multirow[t]{5}{*}{1678} & \multirow[t]{5}{*}{0.551} \\
\hline & 2 & 12 & 0.063 & & \\
\hline & 3 & 5 & 127 & & \\
\hline & 4 & 4 & -0.149 & & \\
\hline & 5 & 7 & 0.702 & & \\
\hline \multirow{2}{*}{$\begin{array}{c}\text { 主な働き手の } \\
\text { 性別 }\end{array}$} & 1 & 44 & 0.217 & \multirow[t]{2}{*}{1011} & \multirow[t]{2}{*}{0.478} \\
\hline & 2 & 12 & -0.795 & & \\
\hline
\end{tabular}

相関比 : 0.65461, 判別的中率 : $91.1 \%$

表-31より,耐震性向上の要因となる項目について， 偏相関係数の大きい順に示すと, 世帯の年収, 主な働き 手の職業, 家族の人数, 主な働き手の性別, 建築年 , 年 齢，居住意向，延へ床面積となる。

また , 表-31に示す項目順に , 耐震性向上の意向を考 察すると， カテゴリースコアがプラスの場合が「向上さ せたい」，マイナスが「向上させなくてよい」を示すこ とから，以下のことがえる .

・世帯の年収が低い方か洏震性向上の意向が高い傾向 
にある . 世帯の年収が 700万円以上では , 耐震性向 上の意向が低い傾向にある .これにより，世帯の年 収が低い世帯が住宅の耐震性に不安を抱いている可 能性があることがうかがえる .

・主な働き手の年齢が 20 代〜50代の世帯では, 年代 に比例して耐震性向上の意向が高くなる傾向にあり， 60 代，70代では，耐震性向上の意向は低い傾向に ある

・建築年が 1950年以前, 1972年〜1981年，1982年〜 1992年の世帯か洏震性向上の意向が高い傾向にある . 一方，1960年〜1971年の世帯の耐震性向上の意向 か低い傾向にあり，耐震性か不十分であることか懸 念される .

・現在地に「住み続けざるを得ない」世帯の耐震性向 上の意向が高い傾向にある

·延へ床面積が $200 \mathrm{~m}^{2}$ 以上の世帯の耐震性向上の意 向が高い傾向にある.

·家族の人数が，1人，3人，5人以上の世帯の耐震 性向上の意向が高く，2人，4人の世帯が低い傾向 にある 。

・主な働き手の職業が公務員の世帯の耐震性向上の意 向か高い傾向にある.

・主な働き手の性別が女性の世帯では, 男性の場合と 比べ, 耐震性向上の意向が低い傾向にある .

c) 接道の幅員の耐震性向上意向への影響

次に , 接道の幅員が , 住宅の耐震性向上の意向への影 響するかどうかについて確認した . まず , クラメール連 関係数を算出したが , 表-28 に示すとおり，值は約 0.05 と小さく，他の項目と比較しても，11 番目の順位とな り，大きな関連性はみられなかった .さらに，このこと をクロス集計とカイ2 乗検定により確認した（表-32）． なお，接道の幅員については，建築基準法第 42 条の第 1項，第 2 項及ひ第 3項の規定を考慮し，調査員力調査 票を配付する際，各戶の接道の幅員が，「18 m未満」， $\ulcorner 18 \mathrm{~m}$ 以上 $27 \mathrm{~m}$ 未満」, 「2 $7 \mathrm{~m}$ 以上 $4 \mathrm{~m}$ 未満」,

$\ulcorner 4 \mathrm{~m}$ 以上」のいずれにあたるかを測定した .

表-32 接道の幅員と耐震性向上意向の関係

\begin{tabular}{|c|c|c|c|c|c|}
\hline \multirow[b]{2}{*}{$\begin{array}{c}\text { 耐震化 } \\
\text { 意向 }\end{array}$} & \multicolumn{4}{|c|}{ 接道の幅員 } & \multirow[b]{2}{*}{ 合計 } \\
\hline & $\begin{array}{l}18 m \\
\text { 末満 }\end{array}$ & $\begin{array}{l}18 n \pi \\
27 m \text { 末満 }\end{array}$ & $\begin{array}{l}27 n \pi 4 m \\
\text { 未満 }\end{array}$ & $\begin{array}{l}4 \mathrm{~m} \\
\text { 以上 }\end{array}$ & \\
\hline \multirow{2}{*}{$\begin{array}{l}\text { 向上させた } \\
\text { い }\end{array}$} & 11 & 74 & 67 & 34 & 186 \\
\hline & $61 \%$ & $54.8 \%$ & $54.9 \%$ & 6. $7 \%$ & 56. $2 \%$ \\
\hline \multirow{2}{*}{$\begin{array}{l}\text { 向上させな } \\
\text { くてよい }\end{array}$} & 7 & 61 & 56 & 22 & 145 \\
\hline & $38.9 \%$ & 45. $2 \%$ & 45. $1 \%$ & 39. $3 \%$ & $43.8 \%$ \\
\hline \multirow{2}{*}{ 合計 } & 18 & 135 & 122 & 56 & 331 \\
\hline & $100 \%$ & $100 \%$ & $100 \%$ & $100 \%$ & $100 \%$ \\
\hline
\end{tabular}

カイ 2 乗值 0.827
有意水準 0.05 (P=5\%值 7.815) としてカイ2 乗検定 を行った結果，有意な差はみられなかった .

アンケートにおいては，「道か狭く，どうにかならな いか」という旨の自由意見闌への記述もあったが，表28 及び表-32より，全体として，接道の幅員は，住民の 耐震性向上の意向にはほとんど影響しないと考えられる． d）建替えにあたっての接道と住宅のセットバックに関 する方策に対する賛否

次に，密集市街地において，住民の自主的な住宅の保 全を促進させるための方策を三つ提案し，賛否を尋ねた . (1) 方策 1

セットバックしても延床面積が咸少しない方策として， 「建替えの際，通常は建物を道路の中心線から 2 m後退 しなければなりません。さらに $0.5 \mathrm{~m}$ 後退すると敷地面 積は今までより減少しますが，3階建てか建築可能とな ります．」(図-2) と示し，この方策に対する賛否を尋

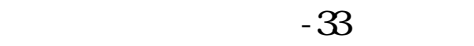

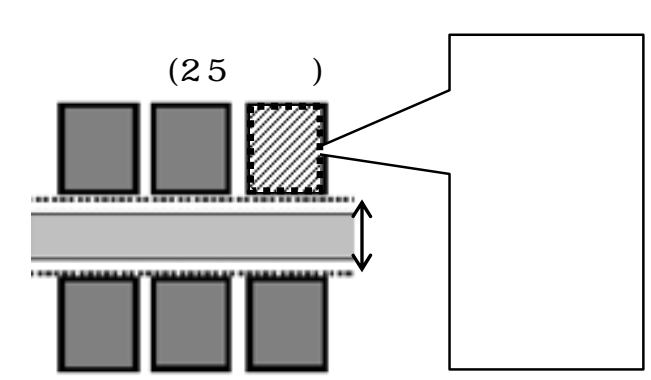

図-2 方策1「道路中心から $25 \mathrm{~m}$ セッバックし 3階建ての建替えを可能とする方策」

表-33 方策1に対する賛否

\begin{tabular}{|c|r|r|r|r|r|r|}
\hline $\begin{array}{c}\text { 耐震 } \\
\text { 化意向 }\end{array}$ & 賛成 & $\begin{array}{c}\text { やや } \\
\text { 賛成 }\end{array}$ & $\begin{array}{c}\text { とちらで } \\
\text { もない }\end{array}$ & $\begin{array}{c}\text { やや } \\
\text { 反対 }\end{array}$ & 反対 & 合計 \\
\hline 向上さ & 16 & 34 & 85 & 20 & 19 & 174 \\
せたい & $92 \%$ & $19.5 \%$ & $489 \%$ & $11.5 \%$ & $109 \%$ & $100 \%$ \\
\hline 向上さ & $53.3 \%$ & $69.4 \%$ & $50.9 \%$ & $80.0 \%$ & $528 \%$ & $56.7 \%$ \\
せなく & 14 & 15 & 82 & 5 & 17 & 133 \\
よい & $46.7 \%$ & $113 \%$ & $617 \%$ & $38 \%$ & $128 \%$ & $100 \%$ \\
\hline & 30 & $49.6 \%$ & $491 \%$ & $20.0 \%$ & $472 \%$ & $43.3 \%$ \\
合計 & $9.8 \%$ & $160 \%$ & $54.4 \%$ & 25 & 36 & 307 \\
& $100 \%$ & $100 \%$ & $100 \%$ & $100 \%$ & $117 \%$ & $100 \%$ \\
& & $100 \%$ & $100 \%$ \\
\hline
\end{tabular}

上段 : 回答数 , 中段 : 行ごとの割合 , 下段 : 列ごとの割合 カイ 2 乗值 11393

有意水準 0.05 (P=5\%值 9.488) としてカイ2乗検定を 行った結果，有意な差があった。これは，「やや反対」 の人のうち，耐震性を「向上させたい」人が $80 \%$ であ ることか影響しているのではないかと考えられる． 
ここで, 表-13 に示すとおり，対象地区の高齢者の割 合か高いことから，方策1に対する賛否について，主な 働き手の年齢による影響があるのではないかと仮設を立 て , クラメール連関係数により確忍した .なお , 比較の ため, 影響する要因について, 密集市街地の状況を考慮 し，世帯の属性及ひ物理的な事項に関するアンケート項 目の中から，「主な働き手の年齢」「世帯の年収」「自 家用車の有無」「延べ床面積」の四つの項目を抽出した． 結果を表-34 に示す．アンケート内容が尃門的であるこ とから，高齢者など「主な働き手の年齢」の関連性力溞 いのではないかと考えたが，3番目の順位であり，強い 相関性はみられなかった 。

表-34 方策1に対する賛否とアンケート項目のクラメール 連関係数

\begin{tabular}{|l|c|c|}
\hline \multicolumn{1}{|c|}{ 項目 } & クラメール連関係数 & 順位 \\
\hline 主な働き手の年齢 & 0.124927 & 3 \\
\hline 世帯の年収 & 0.174475 & 1 \\
\hline 自家用車の有無 & 0.065897 & 4 \\
\hline 延べ床面積 & 0.13667 & 2 \\
\hline
\end{tabular}

\section{(2) 方策 2}

京都などて町並み保全の観点から，建築基準法第 42

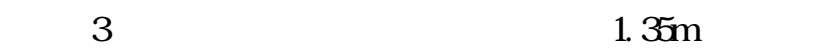
している事例を捉え,「通常建替えの場合，道路の中心 線から $2 m$ の後退が必要ですが, 歴史的まちなみ保全の 必要がある場合, 135 mの後退で建替えが可能です. これにより敷地面積の確保や町並み保全が可能ですが， 自動車通行か制約され緊急車両の通行か困難になり，火 災延焼等の危険性か高くなるお光れがあります.」(図 -3）と示し，この方策に対する賛否を尋ねた。結果を表 - 35 に示す. 有意水準 0.05 ( $P$-50\%直 9.488) としてカイ 2乗検定を行った結果，有意な差はなかった．

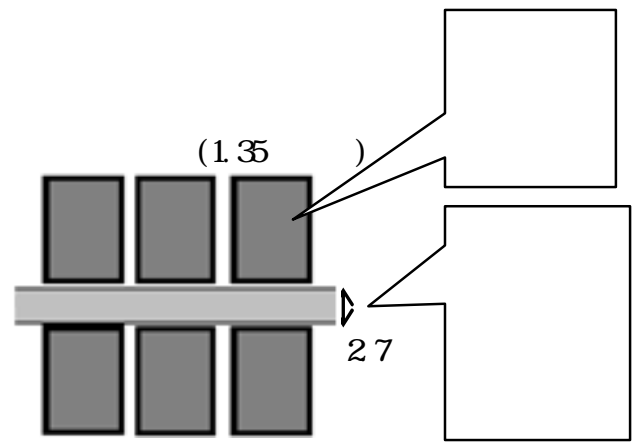

図-3 方策2「道路中心から $135 \mathrm{~m}$ セッドックし 敷地面積確保と町並み保全を可能とする方策」
表-35 方策 2 に対する賛否

\begin{tabular}{|c|c|c|c|c|c|c|}
\hline $\begin{array}{c}\text { 耐震 } \\
\text { 化意向 }\end{array}$ & 賛成 & $\begin{array}{l}\text { やや } \\
\text { 賛成 }\end{array}$ & $\begin{array}{l}\text { とちらで } \\
\text { もない }\end{array}$ & $\begin{array}{l}\text { やや } \\
\text { 反対 }\end{array}$ & 反対 & 合計 \\
\hline \multirow{3}{*}{$\begin{array}{l}\text { 向上さ } \\
\text { せたい }\end{array}$} & 6 & 30 & 80 & 33 & 24 & 173 \\
\hline & $3.5 \%$ & $173 \%$ & $462 \%$ & $191 \%$ & $139 \%$ & $100 \%$ \\
\hline & $54.5 \%$ & $62 \%$ & $526 \%$ & $66.0 \%$ & $50.0 \%$ & $56.7 \%$ \\
\hline \multirow{3}{*}{$\begin{array}{l}\text { 向上さ } \\
\text { せなく } \\
\text { よい }\end{array}$} & 5 & 14 & 72 & 17 & 24 & 132 \\
\hline & $38 \%$ & $10.6 \%$ & $54.5 \%$ & $129 \%$ & $182 \%$ & $100 \%$ \\
\hline & $45.5 \%$ & $318 \%$ & $47.4 \%$ & $34.0 \%$ & $50.0 \%$ & $433 \%$ \\
\hline \multirow{3}{*}{ 合計 } & 11 & 44 & 52 & 50 & 48 & 305 \\
\hline & $3.6 \%$ & $144 \%$ & $498 \%$ & $16.4 \%$ & $15.7 \%$ & $100 \%$ \\
\hline & 1009 & $100 \%$ & $100 \%$ & $100 \%$ & $100 \%$ & $100 \%$ \\
\hline
\end{tabular}

上段 : 回答数, 中段 : 行ごとの割合, 下段 : 列ごとの割合 カイ 2 乗値 6.048

ここで, 方策 2 に対する賛否について，主な働き手の 年齢による影響かないかをクラメール連関係数により確 認した . 前述の「(1)方策1」と同じくアンケート項目の 中から，「主な働き手の年齢」以外に「世帯の年収」

「自家用車の有無」「延心床面積」の三つの項目を抽出 した . 結果を表-36に示す．「世帯の年収」が相関性が いちばん強く，「主な働き手の年齢」は 3 番目であった .

表-36 方策1に対する賛否とアンケート項目のクラメール 連関係数

\begin{tabular}{|l|c|c|}
\hline \multicolumn{1}{|c|}{ 項目 } & クラメール連関係数 & 順位 \\
\hline 主な働き手の年齢 & 0.103001 & 3 \\
\hline 世帯の年収 & 0.130391 & 1 \\
\hline 自家用車の有無 & 0.106230 & 2 \\
\hline 延べ床面積 & 0.095068 & 4 \\
\hline
\end{tabular}

\section{(3) 方策 3}

建築基準法第 42 条第 2 項の規定により，接道力浃あ いで, 建替えできない場合もあることを考慮し，「隣接 する敷地とご自身の敷地を合わせて一つの敷地とみなし， これまて建替えができなかった敷地においても，建替え か可能となります.」(図-4) と示し，この方策に対す る賛否を尋ねた . 結果を表-37 に示す. 有意水準 0.05 (P=5\%值 9.488) としてカイ2乗検定を行った結果, 有意な差はなかった .

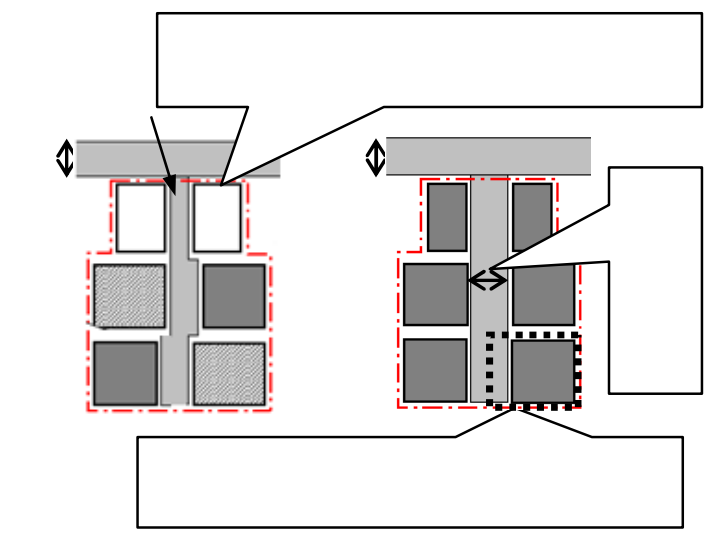

図-4 方策3「接道か狭あいでも建替え可能とする方策」 
表-37 方策3に対する賛否

\begin{tabular}{|c|c|c|c|c|c|c|}
\hline $\begin{array}{c}\text { 耐震 } \\
\text { 化意向 } \\
\end{array}$ & 賛成 & $\begin{array}{l}\text { やや } \\
\text { 賛成 }\end{array}$ & $\begin{array}{l}\text { とちらで } \\
\text { もない }\end{array}$ & $\begin{array}{l}\text { やや } \\
\text { 反対 }\end{array}$ & 反対 & 合計 \\
\hline \multirow{3}{*}{$\begin{array}{l}\text { 向上さ } \\
\text { せたい }\end{array}$} & 14 & 34 & 104 & 10 & 10 & 172 \\
\hline & 81 & $198 \%$ & 60.5 & $58 \%$ & $58 \%$ & $100 \%$ \\
\hline & 483\% & $642 \%$ & $54.7 \%$ & $66.7 \%$ & $526 \%$ & $562 \%$ \\
\hline \multirow{3}{*}{$\begin{array}{l}\text { 向上さ } \\
\text { せなくて } \\
\text { よい }\end{array}$} & 15 & 19 & 86 & 5 & 9 & 134 \\
\hline & $112 \%$ & $142 \%$ & 642 & $3.7 \%$ & $6.7 \%$ & $100 \%$ \\
\hline & $517 \%$ & $358 \%$ & $45.3 \%$ & $33.3 \%$ & $47.4 \%$ & $438 \%$ \\
\hline \multirow{3}{*}{ 合計 } & 29 & 53 & 190 & 15 & 19 & 306 \\
\hline & $9.5 \%$ & $173 \%$ & 621\% & $4.9 \%$ & $62 \%$ & $100 \%$ \\
\hline & $100 \%$ & $100 \%$ & $100 \%$ & $100 \%$ & $100 \%$ & $100 \%$ \\
\hline
\end{tabular}

上段 : 回答数，中段 : 行ごとの割合，下段 : 列ごとの割合 カイ2 2 乗值 3032

ここで, 方策3に対する賛否について，主な働き手の 年齢による影響がないかをクラメール連関係数により確 認した . 前述の「(1)方策1」「(2)方策 $2 」$ と同じくアン ケート項目の中から，「主な働き手の年齢」以外に「世 帯の年収」「自家用車の有無」「延へ床面積」の三つの 項目を抽出した . 結果を表-38に示す.

「主な働き手の年齢」は，1 番目の順位であった .し かしながら, クラメール連関係数としては, 大きな関連 性を示す值ではなかった。

表-38 方策1に対する賛否とアンケート項目のクラメール 連関係数

\begin{tabular}{|l|c|c|}
\hline \multicolumn{1}{|c|}{ 項目 } & クラメール連関係数 & 順位 \\
\hline 主な働き手の年齡 & 0.137865 & 1 \\
\hline 世帯の年収 & 0.135309 & 3 \\
\hline 自家用車の有無 & 0.131701 & 4 \\
\hline 延ベ床面積 & 0.137396 & 2 \\
\hline
\end{tabular}

\section{5 . 研究の結論と今後の課題}

\section{(1)研究の結論}

本研究では, 工務店など住宅等の設計・施工を業務と している建築事業者を対象とした，既存木造住宅の耐震 化に関する認識及ひ耐震化の促進につながる可能性のあ る簡易な耐震補強方法に関するアンケート調査を行うと ともに，金沢市内の密集市街地の住民を対象とした住宅 の耐震性向上等に関するアンケート調査を行い，住宅の 耐震化意向における住宅前面の接道状況の影響の把握， 住宅前面の接道状況を考慮した建替え方策を提案し，住 民の賛否による評価を得た 。

弚の結果，建築事業者においては，簡易な耐震補強方 法により耐震化促進を図るよりも，建物全体を評価し安 全性の確保を図るべきだという安全側の考えであること がわかった .

また，密集市街地の住民においては，狭あいな接道の 状況が, 耐震化意向にはほとんど影響しないことがわか
つた . クラメール連関係数や数量化川類分析から, 世帯 の年収など基本属性か洏震化意向に影響しているといえ る .

さらには，建替えにあたってのセットバックに対して は, 方策1に対しては, 耐震性を「向上させたい」人の 「やや反対」の意見か影響していると考えられる有意な 差があったものの, 全体としては, 「どちらでもない」 力絥半数を占め，「賛成」「やや賛成」と「やや反対」

「反対」はほぼ二分した .この要因として，住民力建築 基準法の規定を十分には理解していない可能性があるこ と，あるいは，住環境は良くしたいものの，敷地面積が 減少することから，セットバックには抵抗があることな どか摊察される .

なお，方策1から方策 3 まで賛否について，主な働 き手の年齢による影響がないかクラメール連関係数に より確認した , 比較のため, 影響する要因について, 密 集市街地の状况を考慮し，世帯の属性及ひ物理的な事項 に関するアンケート項目の中から，「主な働き手の年 齢」以外に「世帯の年収」「自家用車の有無」「延べ床 面積」の三つの項目を抽出した . 光の結果 , いずれの項 目についても大きな関連性を示すものではなかった .

\section{(2) 今後の課題}

建築事業者か安全側の考えであることは望ましいこと であるが, 自治体か推奨している最低限の耐震性能とギ ヤップがあることか洏震化促進の阻害要因とならないよ うにしなければならない。光のためには, まずは, 行政 と建築業界が，市民ニーズ，推進すべき最低限の耐震性 能や簡易な耐震補強方法等について認識を共有するとと もに，行政は建築業界・市場の事情を理解し，建築業界

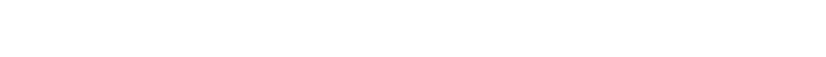
を認識して取り組んでいくことが重要ではないかと考え られる。

また , 密集市街地の住民自らがセットバックや住宅の 建替えを行い防災性向上か图られるかについて可能性を 探ったが, 一般に考えられる要因ではなく，建築や密集 市街地整備に関する専門的な知識がないことや理解でき ていないことか㴗因となり防災性の向上が促進しにくい 状況となっている可能性もあると考えられる.今後，行 政が, 一層広く市民にわかりやすく啓発していく必要が ある

\section{参考文献}

1)警察庁 : 警察白書平成 7 年版, 1995.

2)建設省: 平成 7 年阪神 $\cdot$ 淡路大震災建築震災調査委員会中 間報告書, 1996. 
3)住宅・建築物の地震防災推進会議 : 提言「住宅・建築物の 地震防災対策の推進のために」，2005.

4)平成 18年国土交通省告示第 184 号, 2006.

5) 財団法人日本建築防災協会ホームページ

htt p: //www kenchi kut bosai . or .j p/ , 2010.

6) 国立国会図書館 : 住宅耐震化の現状と課題，ISSE BPE NMEER $568,2007$.

7)総務省 : 平成 10 年住宅 ·土地統計調査 http: //www st at. go.j p/dat a/j yut aku/1998/i ndex. htm, 2010.

8)総務省 : 平成 15 年住宅.土地統計調査

htt p: //Wuw st at. go.j p/dat a/j yut aku/2003/i ndex. htm, 2010.

9)総務省 : 平成 20 年住宅 ·土地統計調査

htt p: //www st at. go.j p/data/j yut aku/2008/i ndex. ht m, 2010.

10) 吉村美保 , 小檜山雅之, 目黑公郎 : 住宅の耐震補強対策に 対する居住者の意識調査, 生産研究, 57 巻 4 号, pp. 164 168,2005 .

11) 目黑公郎，高橋健 : 既存不適格建物の耐震補強推進策に関 する基礎的研究, 地域安全学会論文集, No. 3, 2001

12)村山明生, 古場裕司, 舟木貴久, 城山英明, 畑中綾子, 阿 部雅人 , 堀井秀之 : 既存不適格住宅の耐震性向上に係る社 会技術の研究, 社会技術研究論文集, Vol.1, pp. 338 351, 2003 .

13)小檜山雅之, 石原祐紀, 山崎文雄 : 住宅耐震性能評価に関 わる制度の整備状況と地震リスク低減行動を促す制度の合 理化, 地域安全学会論文集 N. 5, 2003.

14) 大沼正昭 , 田中礼治 , 大芳賀義喜 : 木造住宅の耐震診断促 進に関する研究, 日本建築学会東北支部研究報告会, 2007.

15)石川永子, 中林一樹, 村上美奈子 : 木造密集市街地におけ
る地域力を活かした住宅の耐震化普及啓発活動に関する研 究 - 東京都墨田区京島地区まちづくり協議会の取組み一， 日本建築学会大会学術講演梗概集, pp. 1093 1094, 2008.

16) 宮澤健二：目でみる木造住宅の耐震性，第2版，東洋書店， pp. 237- $328,2008$.

17) 耐震補強研究会編 : 図解・木造住宅の耐震補強, 才ーム社, pp. $69199,2009$.

18) N P O 法人日本耐震防災事業団監修 : 低コストの最新技術 て地震に強い家に変える本, 洋泉社, pp. $29105,2009$.

19) 中村仁, 大串秋穂, 藤賀雅人, 加賀誠, 山本俊哉 : 密集市 街地における建築物のセットバックと外壁間距離にみる道 路空間の実態 - 東京都墨田区京島地区のモデル街区実態調 査 (光の1) - , 日本建築学会大会学術講演梗概集, pp. 897- $898,2009$.

20) 大串秋穂, 中村仁, 藤賀雅人, 加賀誠, 山本俊哉 : 密集市 街地の狭あい道路空間に関する住民意識 - 東京都墨田区京 島地区のモデル街区実態調査 (光の2) - , 日本建築学会 大会学術講演梗概集, pp. $899900,2009$.

21) 東郷哲史, 清水弘樹, 姫野由香, 佐藤誠治 : 路地空間の保 存・維持を目的とした建築基準法第 42 条第 2 項及び第 3 項適用の可能性 - 大分県別府市 ·大分市中心部を事例とし て - , 日本建築学会九州支部研究報告, 第 49 号, pp. 309 312,2010

22)保坂貴司：110 のキーワードで学ぶ 2 世界で一番やさし い木造耐震診断 , エクスナレッジ , pp. 6 17, 2010.

23) 菅民郎：らくらく図解・統計分析教室, オーム社, pp. 158 163 , pp. $238251,2006$.

(2011. 12. 16受付、2012. 2. 29修正、2012. 3. 6受理)

\title{
EVALUATIONS BY QUESTIONNAIRES ABOUT SIMPLE METHODS OF SEISMIC STRENGTHENING AND SETBACK OF HOUSES
}

\author{
Norio MIZUNO and Masakatsu MIYAJIMA
}

Law on promotion of renovation for earthquake-resistant structures was revised in 2006. Since then administrative agencies have been promoting seismic diagnosis and retrofit of houses. But citizens living in densely built-up areas cannot rebuild their houses because of their economic reasons and Building Standards Act regulations. Therefore, we conducted questionnaire surveys of construction companies located in Ishikawa Prefecture and citizens living in Kanazawa City. The results of surveys show that many construction companies are not in favor of simple method of seismic retrofit, and that width of roads hardly influence the citizens' consciousness to renovation for earthquake-resistant structures. 